\title{
Student Marketability: Enhancing Software Skills
}

\author{
Ariffin Abdul Mutalib and Massudi Mahmuddin \\ College of Arts and Sciences, Universiti Utara Malaysia, \\ Kedah, Malaysia
}

\author{
am.ariffin@uum.edu.my; ady@uum.edu.my
}

\begin{abstract}
The government of Malaysia emphasizes content creation for the purposes of nation growth to fill the existing infrastructure. A number of initiatives have been emphasized in latest Malaysian plans. At university levels, efforts were also put to equip students with interests and abilities in the areas of content creation. This paper describes about a training program, as part of student's skill enhancement. The program which was more like a camp was fully conducted by a key player in animation industry. The paper starts with an introduction to the camp. The model of the camp is described, followed with the implementation of the camp. Two assessment methods of the camp are explained, followed with the camp outcome. It was found that the camp was successful in making trainees feel more interested and confident to be animators, and involve in animation productions.
\end{abstract}

Key words: Education, employability, skill enhancement, animation

\section{Introduction}

Number of students graduating from higher learning institutions (HLI) is increasing every year. They are equipped with knowledge in their field, to enter the workplace. The knowledge includes also how the climates in the industries are, and their expectations from the individuals. In the workplace, the graduates are expected to perform what they have learnt in the HLI (Zulikha \& Ariffin, 2005). This will not only be the subject matter contents, but also the soft skill parts such as interpersonal skills, maturity, and ability to perform in various situations. This is the cycle a graduate has to be prepared with.

In HLI, students are provided with contents. HLIs target to equip their graduates with as many knowledge as possible, by providing resources such as qualified instructors, timely technologies, and infrastructures. However, the semester system limits the contents that a course instructor is able to deliver. In computing courses, contents are divided into theory and practical. Theory part could be taught in classrooms, while the practical part requires hands-on approach in computer labs. Instructors will not have enough time to teach the practical parts. As results to this, stu-

Material published as part of this publication, either on-line or in print, is copyrighted by the Informing Science Institute. Permission to make digital or paper copy of part or all of these works for personal or classroom use is granted without fee provided that the copies are not made or distributed for profit or commercial advantage AND that copies 1) bear this notice in full and 2) give the full citation on the first page. It is permissible to abstract these works so long as credit is given. To copy in all other cases or to republish or to post on a server or to redistribute to lists requires specific permission and payment of a fee. Contact Publisher@InformingScience.org to request redistribution permission. dents will have good knowledge on theories, but lack the skills in practicing their theories (Knight \& Yorke, 2004). This then decreases the graduates' confidence and motivations in applying their knowledge. This does not help the graduates to market themselves in the industries, because the industries expect skills from the graduates (Tucker, Sojka, Barone, \& McCarthy, 2000). 
This paper discusses about enhancing students' skills in the practical part so that students are more exposed to skills of employability (Watts, 2006). The previous paragraphs discuss about the trends of teaching scenarios in HLI, and potential dilemmas faced by the HLI in tailoring their computing students. Next, this paper discusses about an initiative planned and run to provide HLI students with enhanced skills. The project was organized by innovative content and application group (iCAAP) (at College of Arts and Sciences, Universiti Utara Malaysia - UUM CAS), which focused on training students to use 3D-animation software. This is also in line with supporting the government of Malaysia which is urging the initiatives in content creation (NITC Malaysia, 2009). The model of the program is provided next, followed with a description on its implementation. Then, some outcomes of the program are addressed.

In line with the growing current technological infrastructure especially the Internet and broadcasting, content has been a need. So, efforts in creating contents should be encouraged. Contents could be developed for various applications such as entertainment, business, and advertisement. This program was organized based on the listed justification:

1. Training by an instructor from the industry on 3D software discloses the needs and desires of the industries from the employees.

2. It increases the Trainees' skills in using 3D software, which will interest the employers to employ the trainees.

3. Trainees will have their own portfolio containing the artifacts they created in the program, which will be good to carry as references.

4. This program is able to create relationship and tighten the existing relationships between the university and the industry. Moreover, from the relationship, diplomatic co-operation could be established.

The program was called iCAAPCamp - because the trainees spent more than 12 hours daily in the computer lab. Trainees were required to be in the lab from 9am to 5am only, but they spent extra hours on their own efforts. The camp was run in two weeks comprising 14 working days. They were off on Friday. Accommodation, Food and beverages, fees, and other benefits were provided by iCAAP, which means trainees did not have to pay for the camp. 17 selected students were approached personally to participate in the camp during the semester break. iCAAP team filtered only students with at least grade B for 'graphic and animation' course to be considered on

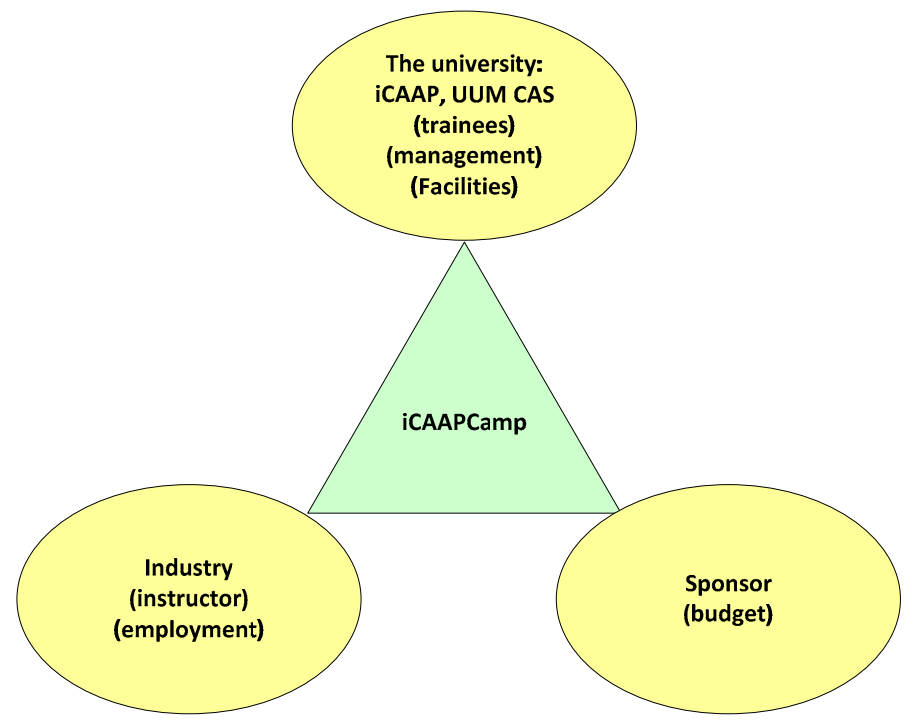

Figure 1: Camp model 
the hypothesis that they are be able to perform well. A special model was designed for this camp, as illustrated in Figure 1.

Figure 1 shows that there are three entities involved in the program: the university, sponsor, and industries to ensure employability (Foster, 2006). The university provides prospective trainees and resources. In such this camp, each trainee must be provided with a computer (which is able to run 3D animation software - in this camp, MAYA was used). Besides, all equipments in a teaching lab such as projector, air-condition, video recorder, audio recorder, and the Internet are required. The university has to provide these facilities to reduce cost, because they are expensive to rent.

The other two entities are sponsor and the industry. Sponsor is a very important entity because running a camp like this requires big budget to win trainees' interest. The trainer was invited from the industry. They were very experienced, producing animated movies and TV-series. Even though expensive, the iCAAP team hired the trainers for the camp because the way they trained is very industry-oriented. Besides the big amount for the trainers, the sponsor was also required for trainees' accommodation, food and beverages, certificate, materials, and management expenses.

The camp involved different parts in 3D animation process. Implicitly, the model contains components of employability as discussed by Pool and Sewell (2007), i.e., career development learning, experience, degree subject knowledge, generic skills, and emotional intelligence. It next section elaborates on how the camp was organized. It was fully implemented by the trainer.

\section{Implementation}

Trainees were required to work on project basis. There were three individual projects and one group project. The individual projects comprised (1) geometrical and bedroom modeling, (2) fruits modeling, and (3) character modeling. While in group, trainees were required to do character animation. The projects evolve from less complicated to more complicated to let the trainees change their mindset and interest slowly (Bandura, 1995). In fourteen days, their projects were assessed by the trainer on formative basis. The trainer was able to establish personal relationship with every trainee, so that it was easy for him to approach each trainee when necessary. The rough schedule of the camp is provided in Figure 2.

\section{Activities}
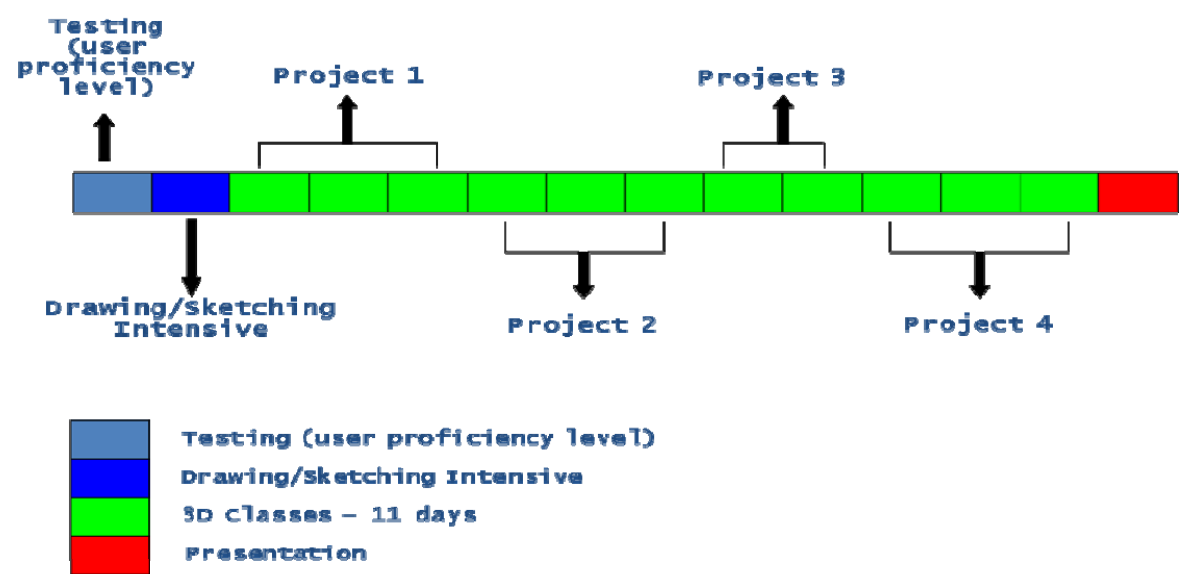

Figure 2: Camp Schedule 
On the first day of meeting, the trainer briefed about the animation industry in Malaysia and in global market. Trainees were presented about the potential of animation, and components of animation. This part was aimed at motivating the trainers besides to break the ice between the trainer and trainees. Also, the trainer made use of this session to know the level of skills each trainee posses. In detail, the first day consisted of these activities: Ice-breaking, demoreel, briefing on animation industry, software for animation industry, 3D animation workflow/pipeline, briefing on tools for learning animation, and question and answer session.

On day 2, trainees went through intensive drawing/sketching exercises. The training started off with basic lines and shapes sketches followed by basic geometry, organic shapes, and characters sketching such as human hands, face and figures. Figure 3, 4, and 5 depict some of the output.

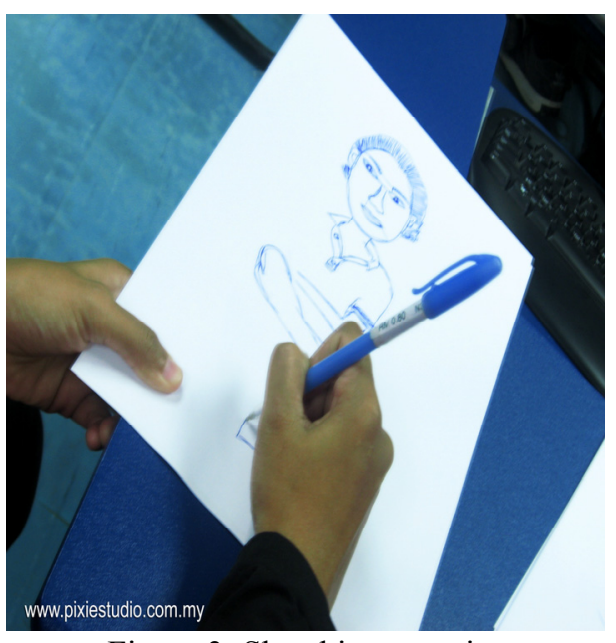

Figure 3: Sketching exercise

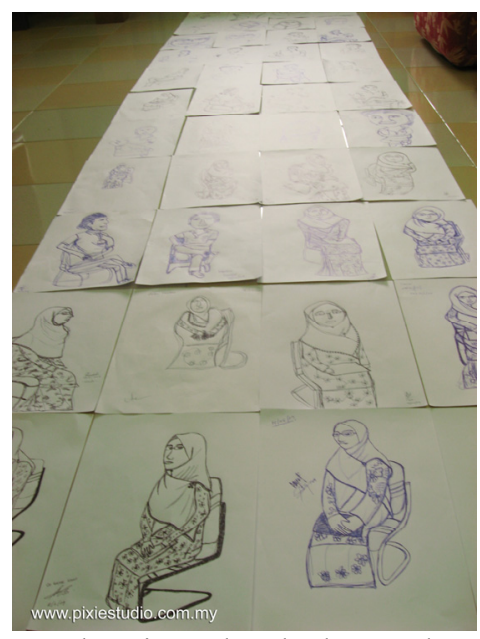

Figure 4: Each trainee sketched a number of drawings for every exercise

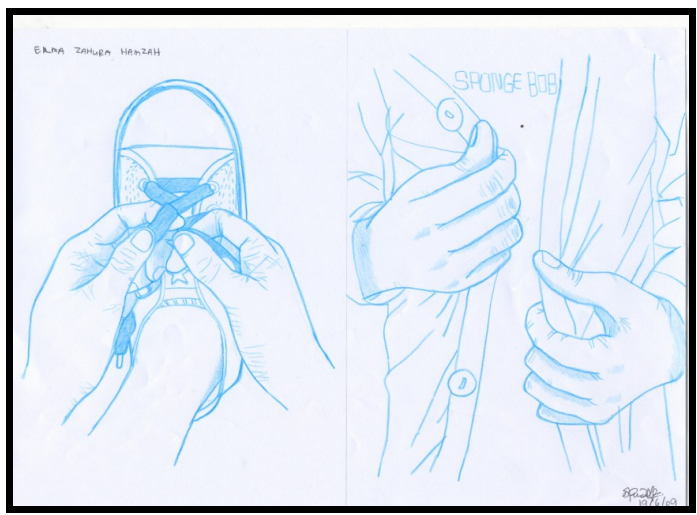

Figure 5: Close-up sketching

Referring to Figure 2, the real training period was divided into four parts from less complicated in geometrical modeling to more complicated in character modeling and animating character in groups. The following paragraphs describe about the 3D classes and the artifacts produced by trainees.

\section{Project 1 (Basic Geometry Modeling)}

Basic geometry modeling project aimed at developing trainees' skills in modeling basic geometry and primitive objects. All detailing such as lighting, texturing and rendering were emphasized 
(Birn, 2006). This is the basic step in 3D modeling. The trainees were assigned to develop a fully furnished bed room using Geometry Modeling technique. Table 1 details the activities on days 3 through 5. Sample of artifacts produced by trainees are provided in Figures 6 and 7.

Table 1: Activities for Project 1

\begin{tabular}{|c|c|c|}
\hline Day 3 & Day 4 & Day 5 \\
\hline $\begin{array}{ll}\text { - } & \text { Filing system } \\
\text { - } & \text { Introduction to Maya } 2008 \\
\text { - } & \text { Basic tools } \\
\text { - } & \begin{array}{l}\text { Project } 1: \text { Bed room (Inte- } \\
\text { rior modeling) }\end{array}\end{array}$ & $\begin{array}{ll}\text { - } & \text { Additional } 3 \text { objects in } \\
& \text { project } 1 \\
\text { - } & \text { Basic to texturing } \\
\text { - } & \text { UV mapping } \\
\text { - } & \text { 3-point lighting } \\
\text { - } & \text { Rendering (TV size) }\end{array}$ & $\begin{array}{l}\text { - } \text { Render occlusion } \\
\text { - } \text { Render single frame } \\
\text { - } \text { Animating fan } \\
\text { - } \text { Playblast } \\
\text { - } \text { Project 2: Exterior model- } \\
\text { ing } \\
\text { - } \text { Research/concept }\end{array}$ \\
\hline
\end{tabular}

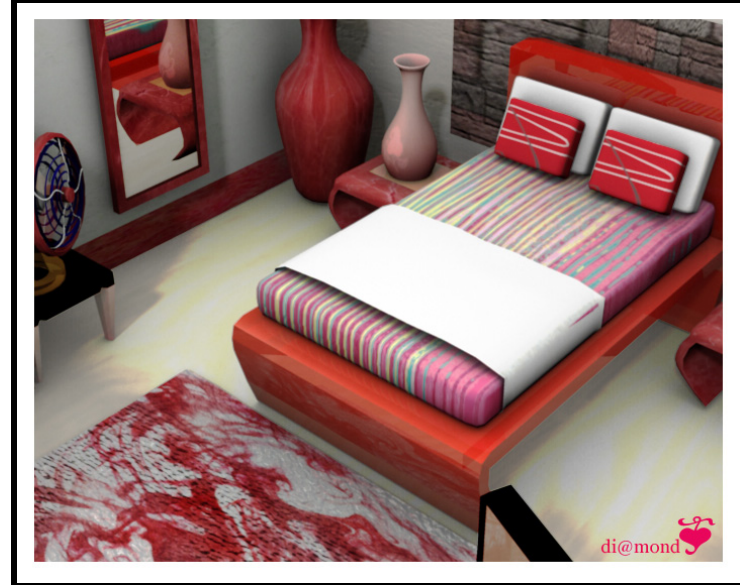

Figure 6: trainees were required to model a fan also

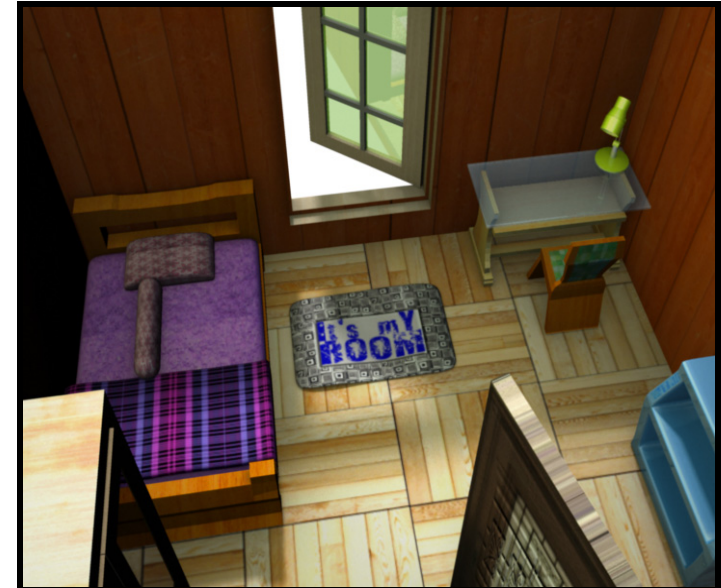

Figure 7: Each project must include detailing such as lighting and texturing

\section{Project 2 (Organic Modeling)}

Having successful modeled the basic shapes in Project 1, trainees were asked to model more complex objects in Project 2. In organic modeling, the trainees were trained to model the shapes of organic objects such as fruits and vegetables. Three days were allocated for Project 2, in which detailed activities are listed in Table 2, while Figures 8 and 9 show samples of works by the trainees.

Table 2: Activities for Project 2

\begin{tabular}{|c|c|c|}
\hline Day 6 & Day 7 & Day 8 \\
\hline $\begin{array}{ll}\text { - } & \text { Continue project } 2 \\
\text { - } & \text { Detailed texturing/effect }\end{array}$ & $\begin{array}{l}\text { - } \text { Layering render } \\
\text { - Comp in Photoshop }\end{array}$ & $\begin{array}{l}\text { - Character modeling } \\
\text { - Head modeling }\end{array}$ \\
\hline
\end{tabular}




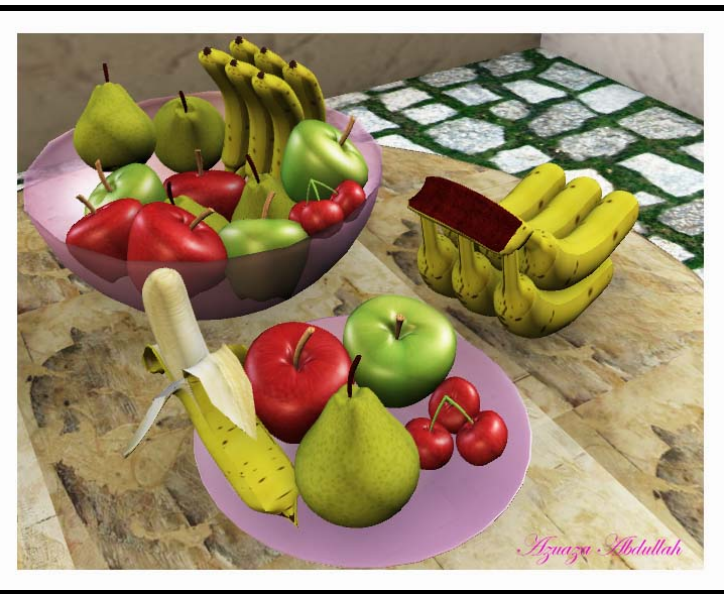

Figure 8: Trainees chose fruits they intend to model

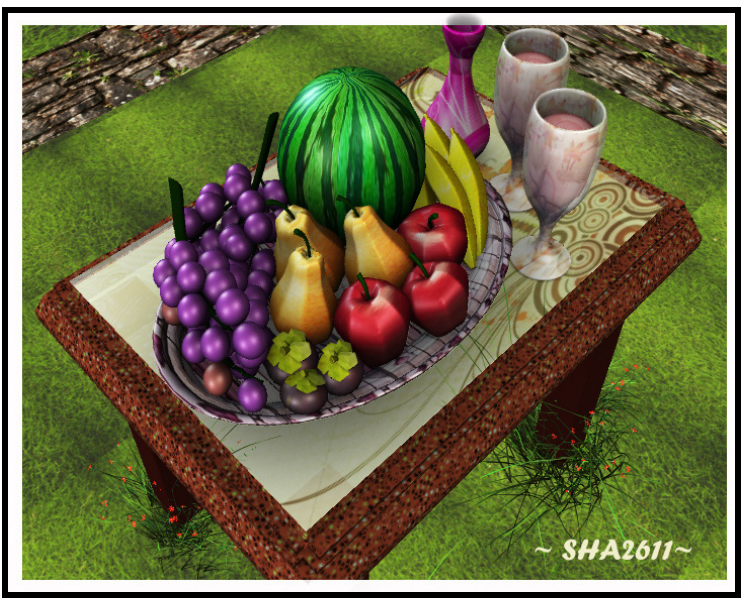

Figure 9: The additional objects such as table and cup are trainees' imagination

\section{Project 3 (Character Modeling)}

Character modeling requires participants to model any characters such as animals, human being, or characters out of their imaginations and creativities. The artifacts from sketches on day 2 were selected for character modeling. Activities for Project 3 are detailed in Table 3. Figures 10 and 11 show the artifacts produced by the trainees.

Table 3: Activities on days 9 and 10

\begin{tabular}{|l|l|}
\hline \multicolumn{1}{|c|}{ Day 9 } & \multicolumn{1}{c|}{ Day 10 } \\
\hline - Character modeling & - Character modeling \\
& - Body \\
& - Shirt \\
& - Hand \\
& - Leg \\
& - Detailed texturing \\
& - $\begin{array}{l}\text { Render 3D turnaround } \\
\end{array}$ \\
& \\
\hline
\end{tabular}

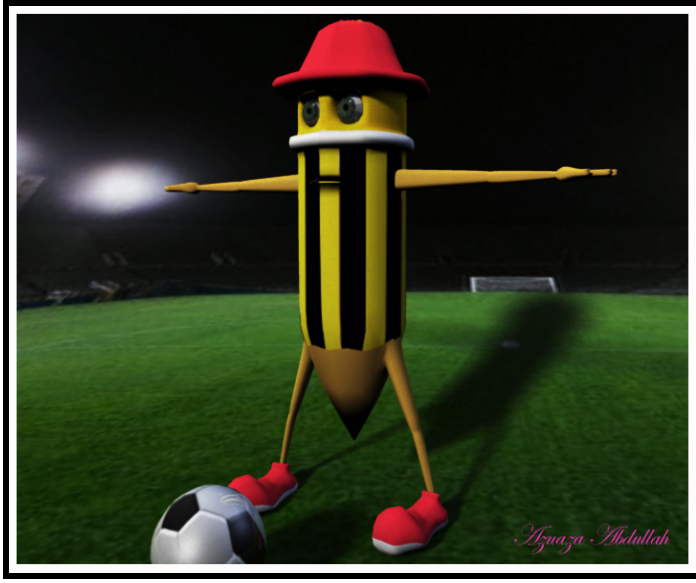

Figure 10: Pencil character as a football player

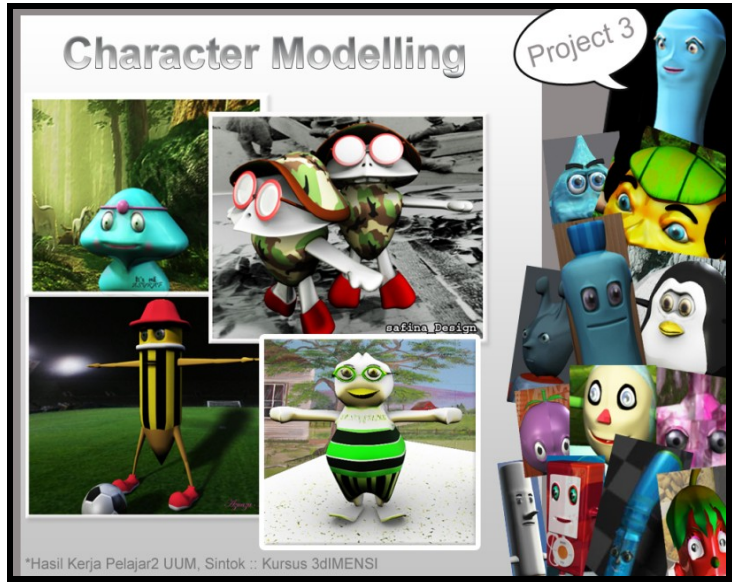

Figure 11: the characters modeled by trainees 


\section{Project 4 (Basic Character Animation)}

Animating the character was done in groups. Each group of maximum 4 trainees was given a 3D file containing a human character model. The days left were not enough for trainees to model the character themselves, because it is complicated as discussed by (Culhane, 1990; Jain, Sheikh, \& Hodgins, 2009). They were required to add physical parts and animating the character. Assessments were based on creativity and accuracy of using the lip sync. Figures 12 and 13 depict the final animation production samples, produced by trainees in three days which involved activities as detailed in Table 4.

Table 4: Activities for days 11 to 13

\begin{tabular}{|c|c|c|}
\hline Day 11 & Day 12 & Day 13 \\
\hline $\begin{array}{l}\text { Final project: i-minute } \\
\text { animation } \\
\text { - Briefing on principles on } \\
\text { animation } \\
\text { - Props and background } \\
\text { modeling }\end{array}$ & $\begin{array}{ll}\text { - } & \text { Importing character } \\
\text { - } & \text { Creating script } \\
\text { - } & \text { Voice recording } \\
\text { - } & \text { Audio editing } \\
\text { - } & \text { Compositing } \\
\text { - } & \text { Video editing }\end{array}$ & $\begin{array}{l}\text { - } \text { Organize files } \\
\text { Backup for final presen- } \\
\text { tation }\end{array}$ \\
\hline
\end{tabular}

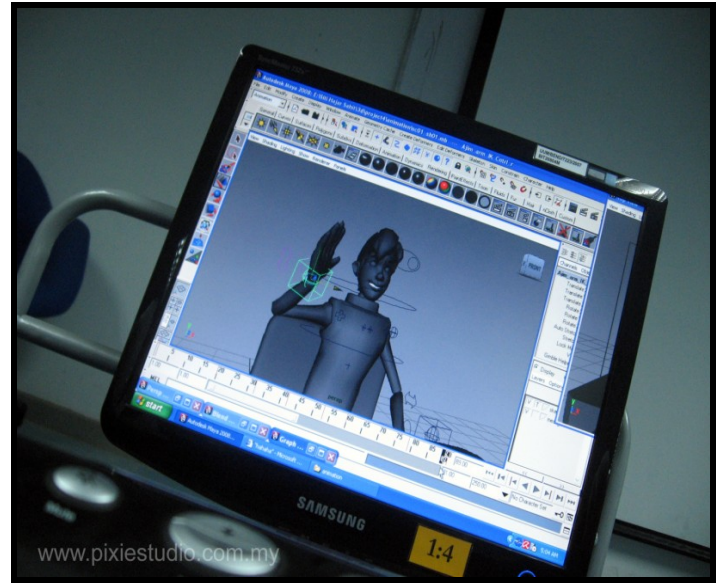

Figure 12: Animating the character

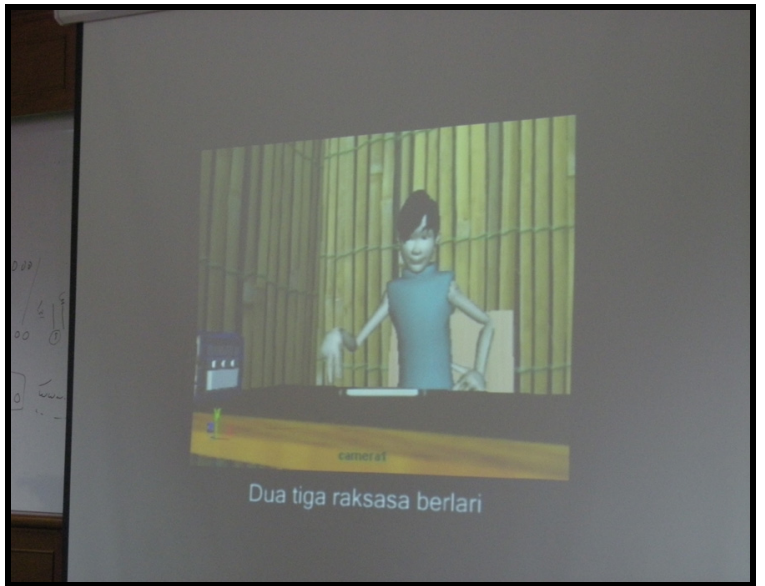

Figure 13: The animation with additional physical parts.

\section{Day 14: final presentation}

Each trainee was asked to present their Projects 1, 2, and 3 individually. Project 4 was presented in groups because it was a group project. Three juries were present on this presentation; two of them are multimedia lecturers of College of Arts and Sciences (UUM CAS). The third jury was a key player in multimedia and animation industry in Malaysia. Besides the juries, other key players in the industries were invited to attend the presentation session for eying the showcase.

The above descriptions contain activities in the camp for 14 days. Artifacts of the activities were also depicted. Next section presents some of outcomes of the camp, which can be divided into the benefits to the trainees and to UUM CAS.

\section{Measuring Camp Effectiveness}

Two methods were carried out to measure whether the camp was effective. The first was a formative assessment in pretest and posttest by the instructor in terms of the level of skills among trainees. The second was through a questionnaire. 


\section{Student Marketability}

In the pretest and post test procedure, trainees were asked to model an object in two hours on day 1. No any of the trainees manage to model, because they were not experienced with the software. In the posttest on day 8, the trainees were found skillful in modeling the objects. Figure 14 depicts the models.
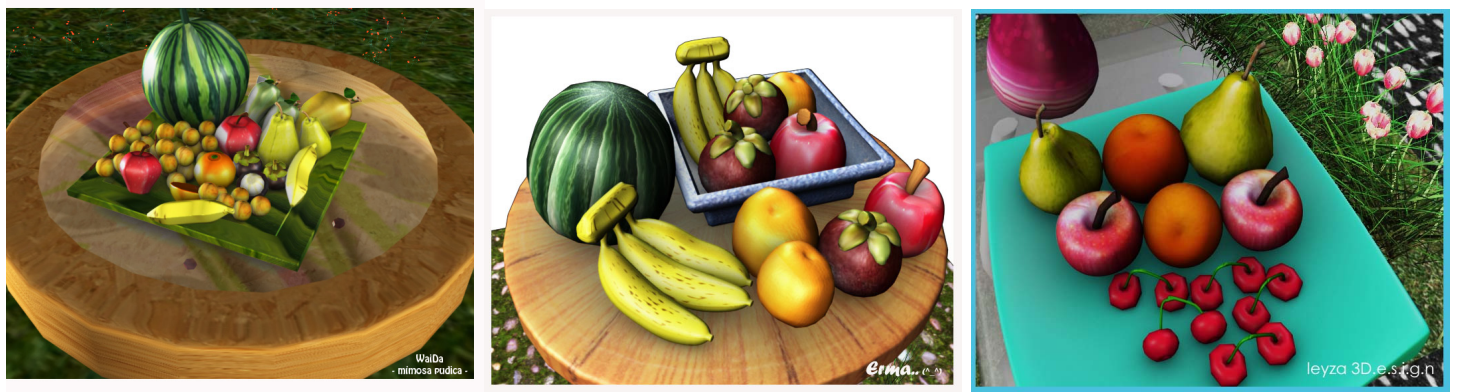

Figure 14: Models created in the posttest

In the questionnaire procedure, a questionnaire was purposely constructed to evaluate this camp (Figure 15). All trainees answered the questionnaire. Results show that all trainees found the camp was very effective in enhancing their knowledge about animation and they agreed that the camp increased their skills in 3D animation software. Detailed results are provided in Figure 16.

\begin{tabular}{|c|c|c|c|c|}
\hline \multicolumn{5}{|c|}{ Soal selidik keberkesanan bengkel perisian animasi 3D } \\
\hline \multicolumn{5}{|c|}{ 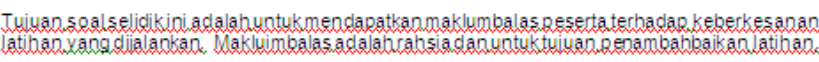 } \\
\hline \multicolumn{5}{|c|}{ Tandakan maklumbalas and a Rad a ruan s yan gdisediakan } \\
\hline \multicolumn{5}{|l|}{ A. Bengakel } \\
\hline & $\begin{array}{l}\text { Sanglat } \\
\text { tidak } \\
\text { setulu }\end{array}$ & $\begin{array}{l}\text { Ticak } \\
\text { setuju }\end{array}$ & Setuly & $\begin{array}{l}\text { Sangat } \\
\text { setuly }\end{array}$ \\
\hline \multicolumn{5}{|l|}{ Saya berpuas hati dengan bengkelini. } \\
\hline \multicolumn{5}{|l|}{$\begin{array}{l}\text { Bengkel inimemberi keyakinan } \\
\text { menghasilkan animasi. }\end{array}$} \\
\hline \multicolumn{5}{|l|}{ Bengkel ini mempertingkatkan prestasi saya } \\
\hline & \\
\hline \multicolumn{5}{|l|}{$\begin{array}{l}\text { Telalui beng gelini, saya mendapat } \\
\text { gambaran jelas cara bekerja di industri. }\end{array}$} \\
\hline \multicolumn{5}{|l|}{$\begin{array}{l}\text { Saya sudah bersedia menceburkan din } \\
\text { dalam industri animasi. }\end{array}$} \\
\hline $\begin{array}{l}\text { Saya menggalakkan rakan-rakan menyertai } \\
\text { bengkel ini. }\end{array}$ & & & & \\
\hline
\end{tabular}

B. Perisian

\begin{tabular}{|c|c|c|c|c|}
\hline & $\begin{array}{l}\text { Sangat } \\
\text { ticlak } \\
\text { setuiu }\end{array}$ & $\begin{array}{l}\text { Ticak } \\
\text { setuiy }\end{array}$ & Setuju & $\begin{array}{l}\text { Sanglat } \\
\text { setuiy }\end{array}$ \\
\hline $\begin{array}{l}\text { Bengkel ini memberi keyakinan kepada saya } \\
\text { menggunakan perisian Maya. }\end{array}$ & & & & \\
\hline $\begin{array}{l}\text { Bengkel ini meningkatkan pengetahuan dan } \\
\text { kemahiran saya menggunakan perisian } \\
\text { Maya. }\end{array}$ & & & & \\
\hline $\begin{array}{l}\text { Saya akan terus meng gunakan perisian } \\
\text { Maya } 2008 \text { untuk projek animasi. }\end{array}$ & & & & \\
\hline $\begin{array}{l}\text { Saya mencxadangkan kepada rakan-rakan } \\
\text { untuk menggunakan perisian Maya. }\end{array}$ & & & & \\
\hline
\end{tabular}

Figure 15: The questionnaire for measuring camp effectiveness 


A. Camp
\begin{tabular}{|l|l|l|l|l|l|l|l|}
\hline & \multicolumn{7}{|c|}{ Items } \\
\hline Trainee & $\mathbf{1}^{\circ}$ & $\mathbf{2}$ & $\mathbf{3}$ & $\mathbf{4}$ & $\mathbf{5}$ & $\mathbf{6}$ & 7 \\
\hline 1 & $4 *$ & 4 & 4 & 4 & 3 & 2 & 4 \\
2 & 4 & 4 & 4 & 4 & 3 & 3 & 4 \\
3 & 4 & 4 & 4 & 4 & 4 & 3 & 4 \\
4 & 4 & 4 & 4 & 4 & 3 & 3 & 4 \\
5 & 3 & 4 & 4 & 4 & 3 & 2 & 4 \\
6 & 4 & 4 & 4 & 4 & 3 & 4 & 4 \\
7 & 4 & 4 & 4 & 4 & 2 & 3 & 4 \\
8 & 4 & 4 & 4 & 4 & 4 & 3 & 4 \\
9 & 4 & 4 & 4 & 4 & 3 & 3 & 4 \\
10 & 4 & 4 & 4 & 4 & 2 & 2 & 4 \\
11 & 4 & 4 & 4 & 4 & 3 & 4 & 4 \\
12 & 4 & 4 & 4 & 4 & 3 & 3 & 4 \\
13 & 4 & 4 & 4 & 4 & 4 & 3 & 4 \\
14 & 4 & 4 & 4 & 4 & 4 & 2 & 4 \\
15 & $\mathbf{3 . 9 3}$ & $\mathbf{4 . 0 0}$ & $\mathbf{4 . 0 0}$ & $\mathbf{4 . 0 0}$ & $\mathbf{3 . 1 4}$ & $\mathbf{2 . 8 6}$ & $\mathbf{4 . 0 0}$ \\
16 &
\end{tabular}

\begin{tabular}{|c|c|c|c|c|}
\hline & \multicolumn{4}{|c|}{ Items } \\
\hline Trainee & 18 & 2 & 3 & 4 \\
\hline 1 & $4^{*}$ & 4 & 4 & 4 \\
\hline 2 & 4 & 4 & 4 & 4 \\
\hline 3 & 4 & 4 & 3 & 4 \\
\hline 4 & 4 & 4 & 4 & 4 \\
\hline 5 & 4 & 4 & 4 & 4 \\
\hline 6 & 4 & 4 & 3 & 4 \\
\hline 7 & 4 & 4 & 4 & 4 \\
\hline 8 & 4 & 4 & 4 & 4 \\
\hline $\begin{array}{l}9 \\
10\end{array}$ & 4 & 4 & 4 & 4 \\
\hline $\begin{array}{l}10 \\
11\end{array}$ & 4 & 4 & 3 & 4 \\
\hline 12 & 4 & 4 & 4 & 4 \\
\hline 13 & 4 & 4 & 4 & 4 \\
\hline 14 & 4 & 4 & 4 & 4 \\
\hline $\begin{array}{l}15 \\
16\end{array}$ & 4 & 4 & 4 & 4 \\
\hline $\begin{array}{l}10 \\
17\end{array}$ & 4 & 4 & 4 & 4 \\
\hline Means & 4.00 & 4.00 & 3.79 & 4.00 \\
\hline
\end{tabular}

Figure 16: Scores by each trainee for each measuring items

\section{Outcome}

\section{Benefits to trainees}

All trainees were selected during the final presentation to do their industrial training in animation companies. Out of 17, one is recruited in the USA, two in Bangkok, and the rest are with Malaysian-based international companies. All expenses for practical training including air-fares, visa, and daily allowances are sponsored. With these encouragements, these trainees are expected to further be employed by animation companies either locally or internationally. Moreover, the companies which employed the trainees for industrial training were interested to employ them as permanent staff after the industrial training period.

\section{Benefit to UUM CAS}

With this training model, UUM CAS will be able to produce graduates with competent skills in animation productions. Besides, UUM CAS has also created diplomatic relationships with the industry players, which in future will assist it in many senses. The success of this camp will be a benefit to apply for grants to organize the similar training model with larger scale.

\section{References}

Bandura, A. (1995). Exercise of personal and collective efficacy in changing societies. In Bandura, A. (Ed). Self-Efficacy in Changing Societies. Cambridge University Press, Cambridge. 1-45.

Birn, J. (2006). Digital Lighting and Rendering ( $2^{\text {nd }}$ Edition). New Riders. USA.

Culhane, S. (1990). Animation From Script to Screen. Thomas Dunne. USA.

Foster, D. (2006). Reflection of a careers advisor. Journal of The Association of Graduate Careers Advisory Services. Nos 117. Summer. 5-6.

Jain, E., Sheikh, Y., \& Hodgins, J. (2009). Leveraging the talent of hand animators to create threedimensional animation. In Proceedings of ACM SIGGRAPH Symposium on Computer Animation (2009). 93-102. ACM.

Knight, P. \& Yorke, M. (2004). Learning, Curriculum, and Employability in Higher Education. Routledge Falmer, London.

NITC Malaysia. (2009). Malaysian Information, Communications and Multimedia Services 886 . Retrieved from http://www.ntic.org.my/index.cfm?\&menuid $=5$ on $1^{\text {st }}$ December 2009. 
Pool, L.D. \& Sewell, P. (2007). The key to employability: Developing a practical model of graduate employability. Education + Training. 49(4). 277-299.

Tucker ,M.L., Sojka, J.Z., Barone, F.J., \& McCarthy, A.M. (2000). Training tomorrow's leaders: Enhancing the emotional intelligence of business graduates. Journal of Education for Business. 75(6). 331338 .

Watts. A.G. (2006). Career Development Learning and Employability. The Higher Education Academy, York.

Zulikha, J. \& Ariffin, A.M. (2005). IT-graduate abilities: performance gap as an input for curriculum improvement. In Proceedings of The $3^{\text {rd }}$ International Conference on Information Technology: Research and Education (ITRE'05). 348-351. IEEE.

\section{Biographies}

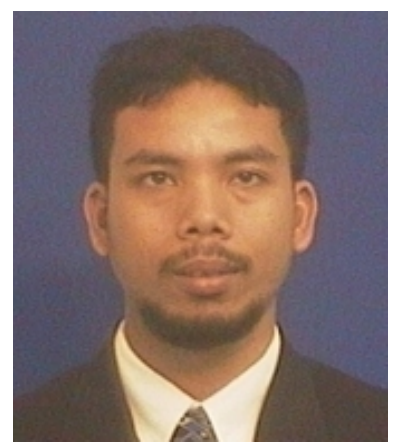

Ariffin Abdul Mutalib (PhD) has obtained a bachelor degree in Information Technology (IT) from Universiti Utara Malaysia (UUM) in 1999. He then continued his study at master level in Heriot-Watt University, Scotland. He finished his Master in Interactive Multimedia (HCI) study in a year (2001). With those qualifications, he teaches at the Faculty of IT, Universiti Utara Malaysia as a lecturer until current. He finished his PhD study in Information Sciences (HCI) in UUM in 2009. Ariffin teaches various subjects at degree and master levels at UUM in the areas of Web Application, HCI, IT, and Multimedia. Besides teaching, Ariffin also supervises master and $\mathrm{PhD}$ students in related areas.

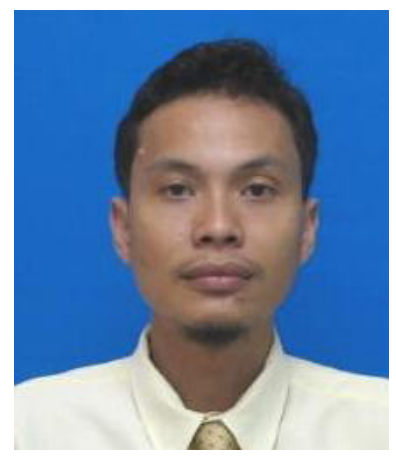

Massudi Mahmuddin is a lecturer at Universiti Utara Malaysia. His interest areas include Software Engineering and Artificial Intelligence. 